\title{
A Tale of Tortured Souls: A Psychoanalytical Study of Toni Morrison's A Mercy
}

\author{
Dr. Ahmed Abdelsattar Abdelaziz Keshk \\ English Department, Faculty of Education, Ain Shams University, Roxi, \\ Cairo, Egypt \\ Shaqra University, Saudi Arabia \\ Email: keshkahmed@yahoo.com \\ Address: Sheraton, Heliopolis, Cairo, Egypt \\ Postal Code: 11757
}




\section{الملخص}

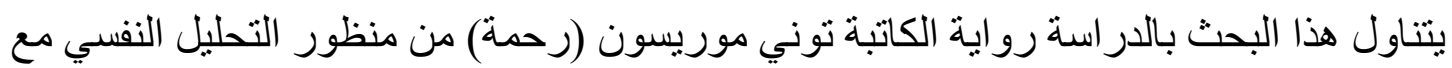

التركيز على دور اللاوعي في توجيه سلوك وتصرفات شخصبات الرواية. ولقد تبنت هذه الورقة البحثية أفكار و افتر اضات فرويد فيما يتعلق بدور اللاوعي كعامل مؤثر في توجيه السلوك البشري، و وذذا المنطلق -

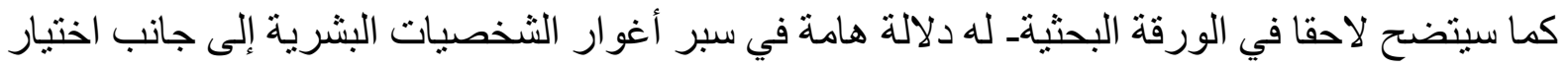
موريسون الموفق لأساليب سرد روائية بعينها لتحقيق هذه الغاية. فطرح التحليل النفسي لأفكار وأساليب موريسون الروائية يمكن القراء من خلق معاني و أفكار جديدة في فهم الأدب الأفرو أمريكي. وتتنهي هذه هذه الورقة البحثية إلى إثبات أن الثخصية المستقرة هي الثخصية المتسمة بالاتز ان بين جو انبها الاجتماعية و النفسية.

الكلمات المفتاحية: رحمة، تحليل نفسي، فرويد، موريسون، الأدب الأفرو أمريكي 


\begin{abstract}
This paper examines Toni Morrison's A Mercy from a psychoanalytic perspective with significant reference to the role of the unconscious in directing the characters' behavior. Sigmund Freud's ideas and postulations have been adopted in this paper. To Freud, human behavior is directed by factors which are usually unaware to the humans 'the unconscious'. This idea -as explained later in this paper-is significant in a sense that it reveals new hidden dimensions of human characters through Morrison's successful choice of a certain literary narrative technique. The psychoanalytic reading of Morrison ideas and techniques helps readers to create new meanings and to provide new ideas in understanding African American fiction. Finally, this paper tries to prove that a stable character is a balanced character in which the social and psychological aspects are wellintegrated.
\end{abstract}

Key Words:A Mercy, Psychoanalysis, Freud, Morrison, African American Fiction 


\section{A Tale of Tortured Souls: A Psychoanalytical Study of Toni Morrison's A}

\section{Mercy}

This paper studies the unconscious dimension of the fictional characters of Toni Morrison's A Mercy. The general trait of the majority of her characters in the novel is their absurdity that makes them a threat to themselves and the people around them. This absurd behavior is derived mainly from their fear of the unknown. All of them fear the future and do not show any faith in a better tomorrow. In most cases, these personal features are indicators of serious psychological conflicts in the characters' unconscious side. Thus, a psychoanalytical reading of A Mercy focuses on how the unconscious deeply-shapes the characters' actions and behaviors, taking into consideration the effect of the surrounding circumstances. The characters of A Mercyare mainly 'types' since they represent individuals or collectives in the African-American society.

In this paper, the psychoanalytical approach, especially the ideas of Sigmund Freud are adopted in the analysis of A Mercy. For Freud, human behavior is directed by factors which the individuals are not usually aware of which he calls 'the unconscious'. The study endeavors to show the significant role of the unconscious as well as the social, historical and cultural factors that shaped the characters of A Mercy.

Slavery and the quest for freedom have been the predominant themes in the history of African-American literature. During the Trans-Atlantic slave trade, which lasted for almost 400 years, thousands even millions of Africans were arrested and transported across the Atlantic to work in coffee, sugar, and cotton plantations in America. Many of them died in the process whereas others also died under the whips of slavery while working. Historically, the Blackman's horrible experience of slavery stands out as the worst level of human degradation. J.Baldwindescribes this idea by saying, "for the horrors of the American Negros' life, there has been almost no language". Thus, the recent African-American community came from different and various backgrounds, religions, and nationalities. Over the horrible years of slavery, black men tended to group and cluster together taking as their unifying force the horrible physical and psychological experience they all witnessed. 
Slavery has ended after the brave honored participation of the black slaves in the revolutionary war of 1975 . The courage demonstrated by the blacks led to the emancipation of black people that in turn ended slavery in the United States. African-American literature that started at this period marks a prominent change in the history of Black Americans. African-American literature covers certain topics that mainly revolve around the quest for identity, equality, freedom and their recognition as citizens of complete rights and responsibilities. Thus, African literature was considered the pulpit of African-Americans to express their case and their claims to their humanity.

Consequently, African-American literature was colored with the soul and the narratives of Black Americans including Blues, Spirituals, gospels and classic slave narratives.M. Miederisummed up the features of the African-American literature by saying, "inspired and tragically built around the core experience of slavery and racism, the quest for freedom, liberty and identity... which is given expression under different theories such as Socialist Realism, Black Nationalism and African Feminism" (10). The most recent topic of interest to AfricanAmerican literature is the theme of black women's experience with the surrounding backgrounds with its horrible racial and sexual discrimination. The works of many African-American dramatists and fiction writers won the heart of millions of readers as well as academic and international prizes. Black women writers like Zora Neale Hurston, Maya Angleou, Jamaica Kincaid, Toni Cade Bambara, Alice Walker and Toni Morrison succeeded in creating their own literary canon.

African-American novels are largely sociological. Many researchers have approached these novels from the angles of racism, patriarchy, sexism, discrimination and marginalization. However, the psychoanalytic assumption that is the fear of the unknown is the unconscious motivation that shaped and formed the behavior of both the black and the white characters inA Mercy. Based on the psychoanalytic criticism, this paper explains how the different concepts and ideas of this field can be applied on Morrison's A Mercy. The characters of the novel are mainly representing themselves as well as the major psychological and social types they belong to. Thus, an evaluation of the sociocultural behavior of the characters of $A$ Mercy based on their unconscious tendencies is provided in the light of Freud's ideas. 
Freud's psychoanalytic theory has deeply affected the study of human psychology and personality development in many fields such as literature, philosophy, art, and psychology. Modern thought has been deeply influenced by Freud's theory that has been modified with recent concepts and ideas. Freud believes that human behavior is the result of ideas, thoughts, and hopes that exist in a person's own psyche yet they are not that easy to be accepted by the conscious side of the mind. This reservoir of ideas which are unknown is called the unconscious. Thus, psychoanalytic theory suggests that most of the characteristics of any individual are just a reflection of this unconscious side of the mind with all its feelings, thoughts, and ideas. These feelings and ideas are usually repressed to the unconscious because they usually negatively affect self-esteem. However, the unconscious side of the mind resurfaces in different forms as in hallucinations, flashbacks, painful memories, and nightmares. Another related idea of Freud's theory is the sexual repressed motivating power that is responsible for many human's actions. This sexual side is released indirectly in dreams, jokes, and clearly in literary works. Thus, Freud believes that literary works are the vehicles for expressing unconscious sexually repressed motivations and ideas that control the human behavior. (Freud, The Basic Writings of Sigmund Freud)

Psychoanalytic literary criticism started with the study of the author's life in relation to his/her works in general and characters in particular; this is known as psychobiography. This way of analysis begins with studying the biographical information of the author from various sources using it to analyze his literary works. However, psychoanalytic literary criticism has turned its attention to character analysis rather than psychobiography. Many critics believe that the main character in a work of art is usually a reflection of the author's views and vision. The individual characters in a text have become the focus of analysis rather than the biography of the author. D.Westen summarizes the idea of psychoanalysis by saying that it reflects:

the importance of conflicting mental processes; unconscious processes; the influence of the past on current functioning; the enduring effects of interpersonal patterns laid down in childhood; and the role of sexual and aggressive wishes in consciously and unconsciously influencing 
thought, feeling and behavior is the degree to which it can be considered psychoanalytic. (22)

Also McCartney provides a comprehensive summary of the psychoanalytical approach; psychoanalysis aims to "understand individuals by uncovering desires hidden deep within the mind and revealing their connections with the conscious surface." He also highlights the idea that "for the critic undertaking a psychoanalytic reading, three Freudian categories are essential: the unconscious; the sexual origin of human motivation in repressed infantile incestuous desires; and the symbolic manifestation of unconscious wishes in dreams, jokes, errors and significantly in literary works" (qtd. in Green 597).

In Morrison's A Mercy, many motives and absurd actions of characters can be explained in the light of Freud's idea of the unconscious. For example, Sorrow is known that she has always "talked out loud when alone" (152). Similarly, Rebekka also gives directions to herself when she is alone. This idea applies also to Lina who answers birds as if they were asking her advice on how to fly (152). Florens, as well, is directed by the strange unconscious mixed feelings of her bitter childhood experience. All of these examples review the role of the unconscious in controlling the characters' behavior. Freud's theory of the unconscious is still predominant nowadays in literary criticism.

Freud affirms that most of our behaviors are directed by the unconscious factors even though we are not aware of that. Moreover, he provided a classification of the mind into three main categories, namely theid, the ego, and the super-ego in an attempt to show how the individual personality develops and to try to diagnose the exact reasons of the mental illness. To Freud, the id refers to the basic instinct and urges which are completely unconscious. The id works to satisfy the biological needs such as thirst, hunger, and sex. The id targets joyful life and avoids painful things. The ego which is known as the self is totally different from the id since it is partly conscious and partly unconscious. The ego is governed by the reality principles, in other words, the ego endeavors to satisfy the needs of the id in a real not in an imaginary way. The super-ego, on the other hand, is mainly controlled by the moral ideas learned from the family and the society. The super-ego is responsible for guilt and shame when one completely follows his id. The super-ego is also responsible for one's feeling of pride when satisfying the different needs in a 
correct moral way. To Freud, a healthy character is the one balancing between the id and the super ego. (Freud, Introductory Lectures on Psychoanalysis, 27)

It is significant to remark that Morrison's A Mercyproves that there is a relation between psychology and literary creativity especially in her portrayal of the major characters. Morrison is fully aware of the significant role of the unconscious in directing the behavior of her characters. For example, the act of aMinha Mãe, Florens' mother, when she released her eight-year-old daughter Florens in order to pay her master's debt instead of herself or her little boy. Her unconscious motivation to do this is to protect her sense of woman dignity. Thus she says:

There was no protection and nothing in the catechism to tell them no. I tried to tell Reverend Father. ... To be female in this place is to be an open wound that cannot heal ... $(162-163)$

The psychoanalytic theory of Freud introduces the concept of "the return of the repressed" to clarify the hidden component of the human nature and what he describes as the unconscious. These elements (desires, thoughts, and feelings) are believed to be hidden because they are not acceptable to the individual or to the society. Nevertheless, the individual behavior of the person shows the conflict when what is repressed is replayed in the unconscious by the means of hallucinations, nightmares, flashbacks, and compulsions. Examples and signs of psychological repression are clear in all the characters of Morrison's A Mercy. All of them had a tragic past of painful slavery experience that is usually related to their own personal painful stories. So it would be logical to illustrate and prove how these repressed feelings, thoughts, and ideas reappear from the unconscious of the characters to affect and control their own behavior. From this point onward, it identifies the unconscious motivation for the behavior of these characters. (Freud,Introductory Lectures on Psychoanalysis, 43)

As explained before, repression in the unconscious is responsible for directing the behavior of the characters of Morrison's A Mercy. Morrison's protagonists-Rebekka, Sorrow, Lina, and Florens- tried hard to speak out their repressed feelings and thoughts. Rebekka does always give directions to herself 
while being at some solitary tasks. Sorrow is "thought to be daft because she talked out loud when alone but who didn't?" (152). Also Lina is keen on answering birds "as if they were asking her advice on how to fly" (152). All of these acts reflect clear repressed conflicts in the unconscious side of the characters which is presented in their behavior.

To study these characters in detail, the analysisstarts with Sorrow. As her name clearly indicates, Sorrow suffers from real painful unconscious repressed memories. Sorrow is the third slave next to Florens and Lina in Jacob's farm, Morrison portrays her with "black teeth and a head of never groomed wooly hair, the color of a setting sun" (120). Her repressed unconscious feelings start once her father's ship was taken along with everything else. Sorrow was in deep sleep that moment because of the surgery on her neck and was left alone on the shore where the Sawyers saved her:

They had met beneath the surgeon's hammock in the looted ship ... when the ship foundered she did not know it, and if any unmurdered hands and passengers escaped, she didn't know that either. What she remembered was waking up after falling to the floor under the hammock all alone. Captain, her father, nowhere ... Sorrow had never lived on land ... Now the memories of the ship, the only home she knew, seemed as stolen as its cargo: bales of cloth... Even the trace of Captain (her father) was dim....(117)

It is clear that Sorrow didn't know anything about herself or her family and she was named 'Sorrow' by Sawyer's wife because "she was abandoned" (120). Morrison describes Sorrow as a girl "who kept wandering off, getting lost... a strange melancholy girl to whom her sons were paying their close attention" (120).

Even other female characters such as Lina and Scully have noticed Sorrow's strange behavior. Scully says "the look of her was daunting, complicated, distant. The unblinking eyes, smoke gray, were not blank, but waiting. It was that lying-inwait look that troubled Lina. Everyone but himself thought she was daft because she talked out loud when alone..." (151). To Lina, Sorrow is a miserable character 
with a tortured soul "In Sorrow's presence eggs would not allow themselves to be beaten into foam, nor did butter lighten cake batter..." (55). It becomes clear that Morrison portrays Sorrow as a girl with a tortured repressed unconscious or even with a conscious denial of her painful life where all her painful memories are buried in the unconscious to be forgotten. Sorrow fools herself as well as the others by thinking that these repressed memories have been deleted completely from her life. By pretending that she does no longer remember her past, Sorrow is actually repressing her feelings in a way that makes all her behavior a prey to these repressed memories "not then, not ever, had she spoken of how she got there or where she had been" (49).

Unfortunately, Sorrow's repressed memories find a way to her consciousness. This is embodied in Sorrow's strange melancholy. Aggravating her tortured soul and painful memories, Sorrow has been raped many times by Sawyer's boys. Like all of her past repressed painful memories that shifted to the unconscious, Sorrow cannot remember what really happened. Narrating these events to Twin, Morrison succeeds in showing how mindless Sorrow has become:

The housewife told her it was monthly blood;... Twin and she talked about it, about whether it was the result of the goings that took place behind the stack of clapboard, both brothers attending instead of what the housewife said. Because the pains was outside between her legs, not inside where the housewife said was natural... (120).

Sorrow does not even know her real age. When asked about her age, she answers "I believe I have eleven years now" (120). However, the clearest sign of her tortured repressed unconsciousness that shows her psychological serious conflict between the id and the super-ego is Sorrow's invisible Twin. Freud describes such a case as "a split" character:

She did not mind when they called her Sorrow so long as Twin kept using her real name. Having two names was convenient since Twin couldn't be seen by anybody else. So if she were scrubbing clothes or 
herding geese and heard the name Captain used, she knew it was Twin. But if any voice called 'Sorrow,' she knew what to expect. Preferable, of course, was when Twin called from the mill door or whispered up close into her ear. Then she would quit any chore and follow her identical self. (116)

The appearance of Sorrow's invisible Twin usually occurs when Sorrow loses all she has. Twin identifies with Sorrow's past, appreciates her effort and understands her fears. That made her the best companion ever that Sorrow can get one day. "Twin... was her safety, her entertainment, her guide" (119). When filled up Sorrow's life, physically, emotionally, and spiritually, Twin was always there to back her up.

In the previous quotations, Morrison clearly describes Sorrow's fragmented character. Sorrow's Twin is her inner self that can help her make sense of the surrounding events. Twin has undeniable role in building up Sorrow's selfconfidence. This idea is clearly noticed at the birth of Sorrow's last baby. After experiencing the beautiful feeling of love, and unlike the previous babies who died at birth, Sorrow peacefully watches her baby with a rooted sense of motherhood. Thus, preoccupying her mind and heart on the baby, Twin signs out of Sorrow's life leaving Sorrow and her baby no longer "concentrating on the art of escape" (121). Sorrow "knows what to name her baby. Knew also what to name herself" (134), Sorrow began to organize and control her own life. She is no longer wandering aimlessly. Sorrow proudly and confidently says "I am your mother... my name is complete" (134).

Another character introduced by Morrison is Lina. Lina is an example of Freud's idea of torn unconscious due to major painful events. Lina has witnessed merciless brutal mass execution of innocent people in her village. These memories of death, shame, and devastation have haunted Lina and tortured her unconscious. Lina's way to relief her restless unconscious is to narrate her cultural and historical past. In the following quotation, Lina resorts to the same technique with Florens to relief out these haunting memories: 
Sudden a sheet of sparrows fall from the sky and settle in the trees so many the trees seem to sprout birds not leaves at all. Lina points. We never shape the world she says. The world shapes us. Sudden and silent the sparrows are gone. I am not understanding Lina. You are my sharper and world as well. It is done. No need to choose. (71)

This story describes the suffering of the black. It is considered as a warning to Florens from thinking of crossing the lines one day. Lina warns Florens because the latter seems to build high hopes on living a peaceful normal life in a social and cultural environment built around slavery. Thus, Lina advises Florens telling her that, "We never shape the world. The world shapes us" (72). She keeps telling Florens that their lives are worthless and will never be appreciated or respected.

Lina keeps reminding Florens that the decision of protecting their bodies from sexual harassment was and will never be their own choice. She likens black female slave masters as an eagle "failing forever in trying to protect her babies in eggs from man" (72). Neither Linanor Florens' mother oreven Florens herself will be saved from a slave master who will rape any of them or all of them whenever and wherever he likes.

Since Freud's psychoanalytic theory aims at revealing the repressed feelings and thoughts, he suggests "talking-cure" as a way out for the tormented repressed unconscious. Freud thinks that the talking-cure process comprises collecting and revealing those painful memories in the presence of a selected listener. (Freud, Studies on Hysteria, vol. 2) In this way, talking-cure does not include any form of comments and analyses. From a narrative angle, the talking-cure refers to a narrative in which the victim recollects all the painful memories of the past in a way similar to a confession to a listener who pays a great attention to every single detail and most importantly who identifies with the same horrible memories in order to resolve the conflict.This technique of talking-cure is adopted by Morrison at the beginning of the story when Florens says:

Don't be afraid, My telling can't hurt you in spite of what I have done and I promise to lie quietly in the 
dark weeping perhaps or occasionally seeing the blood once more- but I will never again unfold my limbs to rise up and bare teeth. You can think what I tell you a confession, if you like, but one full of curiosities familiar only in dreams and during those moments when a dog's profile plays in the steam... (1).

The brave step of narrating her painful experiences and memories turns Florens to work out her difficulties. Florens chooses the talking-cure technique to try to control her repressed unconscious in order to gain her self-respect. Her attentive listener is also her lover the unnamed Blacksmith. In A Mercy, Morrison uses narration as a way to free and to cure both Florens and her mother from their horrible past experiences.

Both Florens and her mother are slaves that belong to D'Ortega, a Portuguese slave master who is in debt to Jacob, a trade's man. Jacob goes to D'Ortega to reclaim his money but the latter has no money to give him but instead he offers Jacob his slaves. Although Jacob refuses the idea at the beginning, he later on accepts it when he sees Florens' mother.

He saw a woman standing in the doorway with two children. One, on her hip; one, hiding behind her skirts. She looked healthy enough, better fed than the others. On a whim, mostly to silence him and fairly sure D'Ortega would refuse, he said, 'Her. That one. I'll take her (23-24)

The immediate rejection of Jacob's request to take Florens' mother keeps the reader in wonder. Florens' mother is not only a house slave to the D'Ortega's family. She certainly does many services quite important to the family in general and to D'Ortega in particular. When D'Ortega replies to Jacob's request by saying “Ah, no. Impossible. My wife won't allow. She can't live without her" (24). This answer indicates that "there was more than cooking. D'Ortega stood to lose" (24). It becomes clear that Florens' mother is raped and physically abused by D'Ortega and only for that he keeps her at home. During the conversation between Jacob and D'Ortega, Florens moves from behind her mother while her mother was cradling 
the baby boy on her head. Florens' mother begs D'Ortega to take the little girl not her or the baby boy.

Please, Senhor. Not me. Take her. Take my daughter, Jacob looked up at her, away from the child's feet, his mouth still open with laughter, and was struck by the terror in her eyes. His laugh creaking to a close, she shook his head, thinking, God help me if this is not the most wretched business (24)

This brutal separation of Florens from her mother is actually a dominant action in African American culture. Florens is haunted by this horrible memory that forms a heavy load on her unconscious. Even though she tries hard to talk-cure about that memory trying to explain the possible reasons for her mother's act, she reaches no logical conclusion. This actually causes her many troubles in accepting her self-respect. Florens considered the Blacksmith her only lover and also her attentive listener. The time spent with the Blacksmith is the only time she feels selfreleased and it is also the only time her unconscious does not haunt her. Although Lina tries to warn her that the Blacksmith does not care about her as much as she thinks, she tells Florens that "you are one leaf on his tree" (61) but Florens refuses to believe that by saying "No. I am his tree" (61).

Being deprived of her mother's love, Florens started to search for a social context in which she feels loved again. This explains Florens' misdirected and illogical love to a stranger- the Blacksmith, the black man hired by Vaark to build a new gate for his mansion. Florens at the beginning finds this alternative love in Lina whom she meets in Vaark's house. Florens changed her view to Lina after seeing her shivering in the snow. Only then, Florens thought sympathy for Lina as another slave in the farm; she directs her love to the Blacksmith. Although this love costs Florens her dignity and self-respect, her need for alternative love is more important than her own dignity. This love developed into a possessive desire as Florens cannot live without him. She confesses that "with you my body is pleasure is safe is belonging. I can never not have you have me" (137), "I don't want to be free of you because I am live only with you" (70). Florens gradually forgets about herself completely in order to be with him. She dreams of being his world in a bond that 
can never be broken. This obsessive desire explains Florens' behavior to Malaik, a small orphan boy that the Blacksmith cares of. To Florens, Malaik is a threat to her dream, love, and inner peace.

Now I am seeing a little boy come in holding a cornhusk doll ... You reach out your forefinger toward him and he takes hold of it. You say this is why I cannot travel with you ... he is not to be left alone ... I worry as the boy steps closer to you ... As if he is your future. Not me... (136)

Seeing Malaik in her lover's house brings back all the bitter horrible memories to Florens when her mother preferred her little brother to her. To be rejected by her first lover ever has filled Florens conscious with bitter painful experiences. She has trusted her mother to save her from the strange Mr.Vaark,but depressingly her mother is the one who handed her to him to work as a slave. These nightmares do not stop repeating to the extent that they possessed her to hurt the young Malaik. All what she was thinking of is that she will be abandoned again and the little boy will stay, recalling her past memories. She downloads all her anger on Malaik who replaces her brother at that moment because he is saved, protected and loved by the Blacksmith, just like the case with her brother and her mother. Thus, there is no wonder that this relationship is not healthy and will never last. Florens' ego is incapable of controlling her unconscious. She is not even capable of controlling her action. When Florens attacks Malaik so violently, the Blacksmith runs to check on Malaik ignoring Florens completely. It is even getting worse when the Blacksmith calls her a slave. In this humiliating conversation, Florens says

... I am a slave because Sir trades for me.

No. you have become one.

How?

Your head is empty and your body is wild.

I am adoring you.

And a slave to that too.

You alone own me.

Own yourself woman, and leave us be... You are

nothing but a wilderness. No constraint. No mind (141) 
The previous quotation might sound harsh and cruel as the Blacksmith tells Florens that she is a slave by choice. However, this is the first step towards Florens' therapy. First of all, Florens is a slave to others (Vaark's family). Second, she is a slave to love (the Blacksmith). Finally, she is a slave to herself (she fears to be rejected). Morrison seems to recommend that the only way for Florens to gain her self-respect and identity is to come in peaceful terms with her boss. That is why she goes back to Vaark's house, but this time a new independent person. At the end of A Mercy, Florens succeeds in reconciling with her past in Jacob's house and begins to write on the walls. This symbolizes the change in Florens' character. This house is used to be a site of pain, but now it is a place where she expresses all her feelings and thoughts.

There is no more room in this room. These words cover the floor. From now you will stand to hear me. The walls make trouble because lamplight is too small to see by. I am holding light in one hand and carving letters with the other. My arms ache but I have need to tell you this. I cannot tell it to anyone but you... What will I do with my night when the telling stops? Dreaming will not come again. Sudden I am remembering. You won't read my telling. You read the world but not the letters of talk. You don't know how to. Maybe one day you will learn. If so....come inside this talking room in the daylight. If you never read this, no one will...(161)

In A Mercy, Morrison introduces the readers to what goes through the mind of sixteen-year-old Rebekka, a poor white woman born in London. Like an object, Rebekka was sold by her own parents to be married to the rich Jacob Vaark who has recently inherited a land in an American colony but in need of a wife. Since the very beginning of A Mercy, Morrison shocks her readers with a human experience that is devoid of any aspect of mercy. Believing that her parents do her good, young Rebekka, although being white, was sold and delivered for no reason other than being poor. Moreover, she is bought mercilessly to be a wife and to start a merciful family with a total stranger in a foreign land. 
Rebekka's journey throughout the Atlantic is full of mixed feelings. Throughout a six-week journey, Rebekka was allowed to stay only in "a dark space below next to the animal stalls" (133). No matter what happens, Rebekka will never forget the painful memories of that journey, the darkness, crowded constricted prison-like space and the painful merciless memories of her journey to America. As a poor lower-class passenger, Rebekka was only allowed few moments to leave her horrible place and spend few moments on deck. Although Rebekka is not black and the journey is not meant to be a slave trading one; yet Morrison shows resemblance between poor white female immigrants and enslaved poor Africans. However; Rebekka is in a better condition than any African slave. At least she has the freedom to choose either to travel to America or even to run away andhide in London. Unlike enslaved Africans who are taken to face unknown future, Rebekka at least knows the place she is going to. Her future is not that of a slave with no rights at all, but that of a slave mistress.

Throughout A Mercy, Rebekka's unconscious is loaded heavily with her memories of past painful experience. She has experienced the feelings of being a slave. Her parents sold her to Jacob. This experience kept haunting her even after Jacob's death. Everybody noticed how Rebekka is close to Florens and the other slaves in the farm. This was the case until she succeeded in controlling her unconscious. She decided to act as a cruel mistress. This was indicated by offering Florens for sale. To Rebekka, the common memories with other slaves must be obliterated and any feeling based on these memories should stop immediately. She will no longer treat Florens as her daughter and thus she will never feel mercy for Florens anymore.

The common haunting unconscious factor among all of Morrison's female characters: Florens, Sorrow, Lina, and Rebekka, is their very poor parenting. All of these characters have witnessed painful memories and experienced bitter situations in which their parents failed them. Morrison's female characters have literally lost their parents either physically or psychologically. This has shocked these females and devastated their mental balance. Freud's idea is that some painful experiences to certain people are the main reason for unconscious conflicts that arise in their early childhood and goes out through their adulthood. The absence of a healthy mother-child relationship has caused all of these characters psychological troubles. All of these females, regardless of their different facial, social, and cultural 
backgrounds, have sought comfort in other alternative relationships as a replacement for their parents. Unfortunately, all of these alternative relationships are lost that led to their psychological imbalance.

Freud highlights the idea that in the relation of the child to the different members of his/her family, a child can mature properly. To Freud, there are three essential stages for a child's psychosexual growth, namely the oral, anal, and the phallic. At the oral stage, the child satisfies the need to be loved and stimulated. The child suffers from psychological instability and other conflicts when these needs are not satisfied at all or satisfied in a wrong way. If that happens, the child may either repress this need to haunt the unconscious forever, or will seek an alternative which will lead to the same result as well. (Freud, Three Essays on the Theory of Sexuality, SE, 7) Florens' mother has victimized her daughter and broken the sacred mother-daughter relationship.Being cursed for what she did, Morrison gives an opportunity for Florens' mother to defend herself.She says:

Neither one will want your brother. I know their tastes. Breast provides the pleasure more than simpler things. Yours are rising too soon and are becoming irritated by the cloth covering your little girl chest. And they see and I see them see.... There was no protection. None. Certainly not with your vice for shoes. It was as though you were hurrying up your breasts and hurrying also the lips of an old married couple... There was no protection and nothing in the catechism to tell them no. I tried to tell Reverend Father. I hoped if we could learn letters somehow someday you could make your way... To be female in this place is to be an open wound that cannot heal. Even if scars form, the festering is ever below...(162-163)

Regardless of her attempts to protect Florens, her mother knew her fate. The looks of D'Ortega to Florens say it all. She is doomed to become another servant of his sexual needs. Like her mother and other black females, she will be sexually abused without any complaint. Florens' mother goes on to explain what she did: 
One chance I thought. There was no protection but there is difference. You stood there in those shoes and the tall man laughed and said he would take me to close the debt... I said you. Take you, my daughter. Because I saw the tall man sees you as a human child, not pieces of eight. I knelt before him. Hoping for a miracle. He said yes... It was a mercy offered by a human. I stayed on my knees. In the dust where my heart will remain each night and every day until you understand what I know and long to tell you: to be given dominion over another is a hard thing; to give dominion of yourself to another is a wicked thing. Oh Florens. My love. Hear a tua mae. (167)

The only way out to save Florens - to her mother-is Jacob. Florens' mother is not optimistic since she knows for sure that Florens will be abused and oppressed but she hopes that her daughter will not be raped. She felt better when Mr. Vaark believes that Florens is "a human child not pieces of eight" (167). Florens mother does not mind her daughter to be oppressed as long as she is treated as a human. Sadly, as a mother, this is the better future that she can ever provide for her daughter. Her mother's tears and sufferings are the sufferings and the tears of a long line of black mothers with a long history of inhumane treatment and sexual abuse. In A Mercy, Morrison speaks out the silent voices of the enslaved and the oppressed. The narrative technique that Morrison adopts enables her to achieve this target.

Cleverly, Morrison adopts the stream-of-consciousness narrative technique, to give her readers a deep and honest insight into the unconscious of her female characters. Morrison uses the stream-of-consciousness narrative technique as an opportunity to any female character to speak out whatever crosses her mind. Thanks to the stream-of-consciousness narrative technique, the reader can understand how every character tries to control her unconscious, and also can judge every action in the light of inner conflict from which they suffer. The stream-of-consciousness narrative technique helps also to enhance the psychological analysis of each character. 
A Mercy starts by the narrator's confession to "you". Later on, readers know that the narrator is Florens while "you" is the Blacksmith whereas the confession is inscribed on walls. In A Mercy, like many of her novels, Morrison adopts multifocal narrative technique. Some chapters are narrated by Florens in first person's point of view. Some other chapters are narrated by other characters in the farm in the third person's point of view. The last chapter is narrated by Florens' mother only. This multiple narrative technique allows Morrison to bend the traditional linear-structured narrative. Morrison uses many tactics for the sake of multifocal technique. First, she resorts to multiple perspectives in which she uses multiple narrators to provide their own sides of the main story. In A Mercy, each character tells her personal experience that lacks mercy in a cruel painful world. Second, the untraditional portrayal of the story lines is another tactic of the multifocal technique. The story lines of A Mercy -like traditional novels- have clear and direct connections. Whereas, in many other cases, the story lines are not that obvious to the readers until they cross over. In A Mercy, every character has her story line that comes clear at the end of the novel. Every character is victimized and even double-victimized in a merciless world that might sound different on the outside but cruel and merciless at the core. Readers at - at different occasions- get the feeling that the story of each female character is not related to the other but, at the end of the novel, all the story lines connect in a clear way to reflect the cruelty of the surrounding world.Third, stories within a story is another tactic adopted by Morrison. A Mercy tells many stories within the main story. Every story has its characters, setting, events and yet intersects at the main point, namely the need for mercy.The novel begins with Florens narrating a fact,

I know it is true because I see it forever and ever. Me watching, my mother listening, her baby boy on her hip. Senhor is not paying the whole amount he owes to Sir. Sir saying he will take instead the woman and the girl, not the baby boy and the debt is gone. A minha mãe begs no. Her baby boy is still at her breast. Take the girl, she says, my daughter, she says. Me. Me (7)

Then this plot is narrated by four different persons from different perspectives (polychronic narration). Collaging all of them together, the reader finally finds the 
truth and gains insight to the whole idea. This narrative technique of the novel exploits "different ratios between story time and discourse time to create different narrative effects" (Herman, 215). By story time, it is meant the time presented by narrative whereas discourse time refers to the time used for narrating a story. The first person narration related to Florens' journey in her search for the Blacksmith moves more slowly than the third person narration of the rest of the characters. The longer the duration of Florens' narration, the more attention the readers pay to her story and the details of her journey. Through sets of past events and memories, readers are familiar with other characters, the relationships among them and their life quest for mercy.

The novel also adopts analepsis and prolepsis. Analepsis, to G. Genette, is "an evocation of an event that happened earlier than the point in the story in which it is evoked" (40) whereas prolepsis consists of "narrating or evoking in advance and event that will take place later" (40). A Mercy gives many examples of prolepsis. The reader reaches a full understanding of the event, place and characters that are the subject of prolepsis when facing more information about them later on whereas these examples are not realized as prolepsis by readers at the point of their delivery. When the reader encounters a proleptic situation, he/she frames an incomplete mental image which is kept in memory and only evoked in the process of reading. For example, the death of Sorrow's daughter is told to readers earlier than the information of her birth. This helps Morrison to deliver the characters' need and cries for mercy at the very beginning. In this way, the sympathy with Sorrow lingers and sticks in readers' minds than the happiness of the child's birth. In this sense, Morrison succeeds in directing the feelings and the responses of her readers through the narrative strategies of A Mercy. Similarly, the novel begins with Florens tale of her mother's rejection of her and the devastating effect of that on her life. Thus, readers feel her need for mercy throughout the whole events of the story. Even her mistakes were partially justified in the light of that horrible sense of merciful deprivation. However, the cause of maternal rejection is revealed in the end. D. Herman in his article "Limits of Order" comments on this idea by saying; "the novel, by employing a polychronic mode of narration, where different characters relate a single event, thus arrives at causes, only after a painfully extended exploration of their effect" (73). 
This paper has tried to analyze Morrison's A Mercy to show how repressed memories can come up from the unconscious to direct the behavior of the characters. The behavior of the female characters in the novel has been studied in accordance with Freudian idea of the unconscious. Through this analysis, the paper finds out that the parental relation with children deeply affects the characters' behavior in adulthood. This idea is not related to any social, racial, cultural, and sexual background. It is rather a general human experience than a specific experience related to a certain feature. A Mercy offers a number of female characters who have nothing in common from the outside whereas they share everything in common from the inside. Every female character is double-victimized. These females have been victimized by their families as well as the surrounding society. This makes these characters the perfect choice for applying Freud's theory of the unconscious.

\section{Works Cited}

Baldwin, J. "Letter from A Region in my Mind". The New Yorker, November 9, 1962. Issue: November 17 1962https://www.newyorker.com/magazine/1962/11/17/letter-from-a-region-in-my$\underline{\text { mind }}$

Freud, S. Introductory Lectures on Psychoanalysis Part 1 \& 2. London: Hogarth Press. 1963.

..... Studies on Hysteria Standard Edition of the Complete Psychological Works of Sigmund Freud. Ed. James Strachey. Vol. 2. London: Hogarth (1995).

..... The Basic Writings of Sigmund Freud: Trans and A. Brill Ed. New York: Modern Library. (1938).

..... Three Essays on the Theory of Sexuality, SE, 7 (1905).

Genette, G. Narrative Discourse: An Essay in Method (J.E. Lewin, Trans.) Ithaca: Cornell University Press, 1980. 
Green, Gayle. Making A Difference: Feminist Literary Criticism. London: Routledge. (1985).

Herman, D. Limits of Order, Toward a Theory of Polychronic Narration, Narrative 6, 73. (1998).

Herman, J. Trauma and Recovery. New York: Basic Books, 1992.

Miederi, M. The Ideology of Americanization in Selected Works of James Baldwin.(Unpublished M.A. Thesis). Department of English and Literary Studies, Ahmadu Bello University, Zaria, Nigeria, (2011).

Morrison, T. Unspeakable Things Unspoken: The Afro-American Presence in American Literature. Memory Creation, and Writing Thoughts, (1984).

...... A Mercy.London: Chatto \& Windus, (2008).

Westen, D. Psychoanalytic Approaches to Personality. Theoretical Perspectives University of Michigan, (1985). 